\title{
WHAT DRIVES AIRLINES TO MAKE A CROSS-BORDER INVESTMENT? FIRM-LEVEL FACTORS AND INSTITUTIONAL FACTORS
}

Nobuaki Endo

Tokyo University of Marine Science and Technology, Tokyo, Japan

Toshiya Ozaki

Rikkyo University, Tokyo, Japan

\begin{abstract}
The purpose of this research is to identify the determinants of cross-border investment in the airline industry, focusing on the intangible assets and resources which airlines possess and the institutional differences between home and host countries. The empirical results indicate that airlines have fewer incentives for making foreign investment in other airlines in institutionally different countries and culturally different countries. Furthermore, government restriction on foreign ownership in the host country may discourage airlines to pursue investment in such country. The results weakly support a hypothesis that the more intangible assets airlines possess, the more they may be induced to make FDI. We interpreted the results as follows: the FDI decision of the airline industry may be accounted for by Dunning's Eclectic Paradigm model just as other industries may be; the institutional difference may have an overwhelming impact on airlines for their FDI decisions; and further studies may be necessary in scrutinizing the role of intangible assets of airlines.
\end{abstract}

\section{KEYWORDS}

Foreign direct investment; Institutional difference; Foreign ownership restriction; Intangible assets; LCCs; Eclectic Paradigm

Professor Dr Nobuaki Endo is with Tokyo University of Marine Science and Technology, Japan. Email: nendo@kaiyodai.ac.jp

Professor Dr Toshiya Ozaki is with Rikkyo University, Japan. Email: ozakit@rikkyo.ac.jp 


\section{INTRODUCTION}

Cross-border investments by the airline industry have increased in recent years. Major fullservice European airlines, such as British Airways (UK), Air France (France) and Lufthansa (Germany), have initiated mergers and acquisitions with airlines in foreign countries. These airlines have been consolidated into major airline groups. Furthermore, airlines such as Virgin Group (UK), LATAM (Brazil and Chile), Qantas (Australia), Singapore (Singapore), Air Asia (Malaysia) and Etihad (UAE) have created subsidiaries of their brands in foreign countries.

These and a few other airlines are more actively involved in and exert greater control over the foreign airlines. What drives airlines to expand internationally by way of investing in a foreign country? What firm- and country-level factors may play a key role for an airline to decide on such investments?

The factors and incentives for a firm to decide on foreign direct investment (FDI) have been among the major research topics in international business (IB) studies. IB studies are the leading academic discipline that explores the questions of why, when and how a firm becomes international (Buckley, 2002). Many studies focusing on both the manufacturing and services industries have examined and identified such factors as monopoly power, intangible assets, rivalry relationship, transaction costs, and location conditions, among others. However, past research has largely ignored FDI by the airline industry. With the notable exceptions of Albers et al. (2010), Ramón-Rodríguez et al. (2011), Franco-Arroyave et al. (2014), and Endo (2017), only a limited number of studies have examined major factors for airlines to invest in foreign countries.

The purpose of our research is to identify the firm-level and country-level determinants of FDI by the airline industry, focusing on both the intangible assets that airlines possess and the institutional difference between the home and host countries that they are constrained with. Specifically, it develops hypotheses regarding the impact of intangible assets and institutional difference on FDI decisions based upon IB studies. This research is one of the first studies that examines both intangible assets and institutional difference as determinants for FDI in airlines based upon the statistical regression analysis. 


\section{TREND OF FDI IN AIRLINES}

FDI refers to the firm behaviour in which a firm establishes another firm in a foreign country, known as a foreign subsidiary. By doing so, a firm may transfer its people, capital, management know-how, technology and skills to run business in a foreign market, usually by producing and/or marketing, distributing and selling products and services to foreign clients. A parent firm may establish a foreign subsidiary by acquiring an existing firm in a foreign country (M\&A) or by incorporating a firm from scratch (Green-field investment). To be considered FDI, the investment ratio of a parent firm in a foreign subsidiary should be $10 \%$ or greater.

Since the end of WW-II, trade has become liberalized under the multilateral trade framework, the GATT/WTO system, along with additional regional free trade agreements such as EEA, NAFTA, and TPP. On the contrary, cross-border investment is still regulated by a network of bilateral investment treaties between home and host countries. Furthermore, FDI is often subject to a host of domestic regulations such as safety standards and labour regulations that apply equally to both domestic and foreign firms. It may also be subject to local contents requirements and foreign ownership restrictions that apply specifically to foreign-owned firms.

Because the liberalization of trade has progressed steadily and multilaterally while that of FDI has not, trade and FDI have often been considered a substitute relationship (Caves and Jones, 1985). A firm may internationalize by pursuing a trade instead of FDI as it may face more difficulty internationalizing through FDI. However, in recent years, FDI has become the most important driving force for a firm to internationalize. Even if a firm may want to export, it may need to set up a foreign subsidiary to undertake distribution, sales, marketing, and aftermarket activities. In other words, trade and FDI may be a complementary relationship. Furthermore, a firm may also pursue FDI to establish production capabilities in a foreign country. Accordingly, the amount of FDI flow has far surpassed that of trade (Hill, 2014).

The airline industry is one of a few industries that are left behind this trend. Most bilateral frameworks and domestic regulations establish a rule to restrict FDI in the airline industries. Their goal is that substantial ownership and effective control of airlines operating international air transport services belong to the nationals of the contracting countries. This rule is referred to as the nationality clause.

As such, the scope of internationalization of air transport services has remained limited, and internationalization for many airlines means to transport passengers and cargo from their 
home countries to foreign destinations (Third Freedom) and back (Fourth Freedom). For a few airlines, it also means to transport passengers and cargo between two foreign locations, either by exercising a so-called Fifth Freedom (i.e., two foreign locations are served by a multistop flight originating in one's home country) or a Sixth Freedom (i.e., two foreign locations are served by flights connected through one's home country). However, until recently, few airlines freely transport passengers and cargo between two foreign locations, be they internationally or domestically without involving one's own country by exercising so-called Seventh, Eighth and Ninth Freedoms (ICAO, https://www.icao.int/Pages/freedomsAir.aspx).

Under these restrictive conditions, airlines typically internationalize by establishing foreign branch offices in place of incorporating foreign subsidiary through FDI. A foreign branch office is considered an extension of a home-country organization, most frequently used when the size of the operation is small and the level of strategic, managerial and operational complexity is low (Cerutti et al.,2007). They show stark contrast with many multinational enterprises that internationalize operations by undertaking FDI to set up foreign subsidiaries. These foreign subsidiaries are legally separate entities, even if they are owned and controlled by their parent firms. They are given strategic flexibilities and delegated managerial responsibilities even if they are carefully coordinated with those of their parent firms.

Recently, some countries and regions have reviewed the nationality clause and implemented more liberal revisions to it. As notable examples, the rule of the principal place of business as a substitute for substantial ownership has been adopted in a bilateral framework between Australia and other countries, in a multilateral open-skies agreement comprising the US and seven other countries, and in a multilateral agreement among Pacific island countries (Hocking, 2011; Endo, 2017).

The EU's single market for aviation and its extension, called the European Common Aviation Area (ECAA), and the Australia-New Zealand Single Airline Area (ANZSAA) introduced the common airline operating certificate. They allow nationality over multiple countries and free cross-border investment among countries within these areas. Furthermore, as a substitute provision to effective control, effective regulatory control over airlines by the designated country has been proposed in the ICAO and World Economic Forum (Chang et al., 2004; Endo, 2017). Several governments have responded positively to the proposal and incorporated the effective regulatory control clause into their bilateral agreements. Notable examples include those by Brazil and Colombia. 
Regarding a domestic regulation restricting foreign ownership, the most common upper limit of such ownership is 49\%. Regulations in the US, Japan, Egypt, Saudi Arabia, and a few other countries stipulate that a level of foreign ownership must be less than $33 \%$. However, along with the recent liberalization trend, several countries have removed the upper limit and now allow up to $100 \%$ of foreign ownership, marking a new era of internationalization in the airline industry.

As noted, such airlines as Singapore Airlines (Singapore), LAN (Chile), Virgin Atlantic (UK) and Qantas (Australia) have actively pursued the cross-border investment. They have established their own brand airlines and served routes between two points outside of their home countries. More recently, Etihad (UAE), Qatar (Qatar), AirAsia (Malaysia), Delta (US) and Hainan (China) are rapidly emerging as major sources of such investments. The most common recipients of FDI by these airlines are Europe, Asia, Australia, and South America. ${ }^{1}$

These airlines may represent a breakthrough in the internationalization of the airline industry. By establishing foreign subsidiaries, they may access to a much larger foreign market than the markets that their branch operations have been serving. Equally important, they may be able to undertake a far broader scope of business activities than those activities that airlines with foreign branch operations may pursue by deploying their resources and capabilities that may constitute competitiveness.

It may be obvious that the liberalization of some of the bilateral treaties and the domestic regulations have prompted these front-runners to pursue FDI and have moved their internationalization strategies to the next level. However, are other airlines following suit? Which airlines may more likely pursue FDI in going their internationalization strategies beyond the current level? Likewise, which airlines may more likely continue using branch operations? What may be key driving forces that may make airlines explore a new level of internationalization by pursuing FDI?

\section{LITERATURE REVIEW}

Past research in different schools of thought has identified various incentives for firms to pursue FDI. They include international economics, the industrial organization approach, the transaction cost theory, the institutional approach, the Eclectic Paradigm, and the resource-

${ }^{1}$ Some countries set conditions for $100 \%$ of foreign ownership in airlines. For example, Australia allows up to $100 \%$ only as regards airlines operating domestic services. India imposes $49 \%$ cap on the ownership of foreign airlines. 
based view, among others. Early research by Hymer (1976) uncovers that, if a firm possesses monopoly power, it may be able to exercise such monopolistic power by investing in a foreign market because the market is imperfectly competitive. According to Caves (1971, 1982), a firm possessing transferrable advantages has the desire to use them more effectively overseas, which laid down the economics foundation for the resource-based view.

Knickerbocker (1973) explores the relationship between FDI and the competitive nature of firms in an oligopolistic industry. He identifies the strategic follow-the-leader behaviour as an incentive for FDI. Vernon (1966) expands the Ricardian comparative advantage model to observe different location advantages. He concludes that firms from capital- and technologiesintensive countries pursue FDI in the capital- and technologies-scarce countries at the final stage of the product life cycle in which the product has become standardized, transferring technologies has become easier, and other production factors including labour and materials are abundant and less expensive in such countries. Finally, the transaction cost theory begins by assuming that the market is incomplete, and information and knowledge are uncertain. Therefore, it is economically rational for an organization to perform certain transactions internally rather than through the market (Rugman and Verbeke, 2003).

Dunning has integrated these various approaches into the "Eclectic Paradigm" (Dunning, 2000; Dunning, 1998). According to this view, a firm may select foreign production through FDI rather than through licensing if all the three, not just one or two, advantages exist. The three advantages are an "ownership-specific" advantage based on transferable advantages that a firm possesses, an "internalization" advantage of the incomplete market, and a "location-specific" advantage due to gaining resources that are related to a specific location and that are worth associating with the transferable advantages. Dunning not only integrates all the key approaches on FDI under one platform but also highlights substantial barriers for a firm to endeavour FDI - unless a firm recognizes that all the three advantages exist, it may not be successful in pursuing FDI.

Since the Eclectic Paradigm was introduced, it has become a dominant approach to examining the internationalization strategies of a firm. Many types of research have employed the approach to analyse determinants of FDI in the internationalization of a firm (Ferreira et al., 2011). Those researches have also highlighted difficulties in operationalization, especially in examining the ownership advantage and the location advantage (Narula, 2010).

As for the ownership advantage, such traditional performance indicators as revenues and profits to demonstrate firm-level capabilities, ex-post, have become supplemented by a series 
of "intangible assets" that the resource-based view scholars have introduced. These assets comprise technological know-how, patents, trade-marks, trade-secrets, management skills, brands, and goodwill, among others. They are unique to each firm and constitute a source of competitive advantage of a firm (Barney, 1991; Peteraf, 1993; Grant, 1996; Delios and Beamish, 2001).

A firm that possesses abundant intangible assets may have an incentive to pursue either one of the following two strategies. One is to license them to other firms if a market is perfect, under which such assets may be easily traded between firms and at the same time such a transaction may be well-protected so that a firm may not need to worry about a free-riding problem. Another is to internalize intangible assets by transferring them to foreign subsidiaries through FDI and try to fully exploit them to establish the ownership advantage in foreign markets (Ferreira et al., 2011).

Since few markets are perfectly competitive, firms with a rich pool of intangible assets may face difficulties in licensing them to other firms. This is so because intangible assets typically have high specificity which may not be immediately and directly applicable to other firms (Anderson and Gatignon, 1986; Endo et al., 2014). Furthermore, as Coase's theorem may indicate, a firm may face difficulty in pricing these types of assets appropriately or enforcing transaction in the market because of a high market transaction cost due to specificity and information asymmetry (Caves, 1971; Grant, 1987; Lu and Beamish, 2004). Accordingly, they may thus be more inclined to choose FDI over licensing in entering foreign markets.

The airline industry is no exception. This imperfect market condition may lead to uncertainty when airlines explore opportunities to undertake a market transaction of the intangible asset with other airlines. They may be faced with such difficulties as information asymmetry, opportunistic behaviour, and difficulty in calculating their values through market transactions. Accordingly, they tend to pursue forms of alliances, such as franchising or simple flight cooperation even if they have decided not to undertake FDI to fully transfer intangible assets internally to their foreign subsidiaries (Bouquet et al., 2004; Endo, 2010).

This observation is linked to another one about the market. Markets around the world are not only far from perfect but also different from each other. Traditionally, studies of international economics have focused on factor endowments as the single source of differences among countries that define the pattern of trade and hence, the location advantage of national economies. However, in the last three decades, institutional studies have accumulated 
knowledge about national differences beyond factor endowments and their impacts on the location advantage of national economies and the internationalization strategy of a firm.

These studies have uncovered that markets are institutions and they are institutionalized by both formal institutions such as legal and political institutions and informal institutions such as cultures and social norms (North, 1990; Jackson and Deeg, 2008). Institutions and institutional differences among countries have thus become among the most important measures used to address the magnitude of national differences (Ando, 2012; Endo et al., 2014).

A firm investing abroad must crucially understand differences between its home and host countries not only in factor endowments but also in institutional dimensions. An institution may define utilities of its members including firms and customers, set their behaviour and impact their performance. As Brouthers (2002), Endo and Ozaki (2009), Jackson and Deeg (2008) and Meyer (2001) note, the institution of the host country and its difference from the home country may result in "restrictions, costs or hazards for MNEs" (Jackson and Deeg, 2008: 542).

A firm that conducts business in a foreign country is in a disadvantageous position compared to the local firm and cannot avoid encountering additional costs that the local firm does not (Eden and Miller, 2004; Nachum, 2003). This situation is conceptualized as the liability of foreignness. A previous study notes that the higher the level of institutional difference is, the greater the additional costs of conducting business abroad are (Eden and Miller, 2004; Nachum, 2003; Gaur and Lu, 2007).

Such costs are often divided into three scopes of hazard: unfamiliarity hazards, discriminatory hazards, and relational hazards (Eden and Miller, 2004). Unfamiliarity hazards arise because a foreign firm does not have enough knowledge and experience in the host country (Eden and Miller, 2004, Gaur and Lu, 2007; Caves, 1971). Discriminatory hazards reflect the discriminatory and differential treatment of foreign firms by governments, consumers or the public in the host country (Eden and Miller, 2004). Relational hazards follow the uncertainties in managing both internal and external relationships at a distance, and these hazards result in higher administrative costs (Eden and Miller, 2004; Gaur and Lu, 2007; Endo et al., 2011).

There are studies by Albers et al. (2010), Ramón-Rodríguez et al. (2011), Franco-Arroyave et al. (2014), and Endo (2017) that explore internationalization of the airline industry through FDI from the viewpoints of the aforementioned FDI theories. But other than them, few studies 
have examined FDI activities in the airline industry. These studies that examined the FDI of the airline industry highlight that insights from the FDI theories are relevant to the airline industry. For example, Albers et al. (2010) explain that the three advantages of Dunning (2000) influence FDI in LCCs. In particular, the ownership advantage stemming from capital and ownership structure is important. Franco-Arroyave et al. (2014) note that, in the case of Avianca, the South American airline, its advantage relying on economies of scale, monopoly power, and avoidance of competition motivated the airline to pursue FDI in its neighbouring countries. Endo (2017) focuses on the relationship between institutional difference and FDI through the country level analysis and points out the negative impact of such difference on the bilateral (country-country combination) FDI movement in the airline industry.

However, these studies do not necessarily go into lengths of the theoretical relevance of the Eclectic Model to FDI activities in the airline industry. This is so especially in the level of the ownership advantage and the location advantage based on the analysis of intangible assets and institutional difference. Albers et al. (2010) may be one of the few exceptions that does suggest the importance of intangible assets of airlines in their FDI.

Furthermore, the institutional dimension has been ignored as a factor affecting the decision of airlines in FDI. They show a stark contrast with the studies examining FDI in other industries. Many of them support the idea that the negative relationship exists between FDI and the institutional difference in the manufacturing industry and such services industries as finance, shipping, and tourism. (Buch and DeLong, 2004; Buch and Lipponer, 2007: Gaur and Lu, 2007: Nachum, 2003: Ando, 2012: Endo et al., 2014). The literature thus indicates that, at least in the industries other than the airline, institutional differences have been identified as a key factor that undermines both the ownership advantage and the locational advantage for firms to undertake FDI.

\section{HYPOTHESIS DEVELOPMENT}

\subsection{Intangible assets}

As mentioned, the resources and capabilities of a firm constitute a key foundation of its competitive advantage (Barney, 1991; Peteraf, 1993; Grant, 1996; Delios and Beamish, 2001). According to Barney (1991), a firm generates skills and knowledge and accumulates them as time passes. If they are valuable, rare, difficult to imitate and well-organized for mobilization and execution, they may contribute to sustained competitive advantage. 
A firm that is rich in resources and capabilities has a strong motivation to take full advantage of them. By expanding foreign operations through FDI, firms may be able to use these resources and capabilities across countries and markets and thereby achieve economies of scale, scope, and learning, which contribute to augmented production efficiencies (Hitt et al., 1997; Endo and Ozaki, 2011).

As examined in the preceding literature review section, there were once difficulties to operationalize firm-level resources and capabilities in analysing the ownership advantage of the Eclectic Paradigm model. Traditionally, such performance indicators as revenues and profits were employed to demonstrate firm-level capabilities ex-post. However, in recent years, they have become supplemented by "intangible assets" that the resource-based view scholars have introduced (Barney, 1991; Peteraf, 1993; Grant, 1996; Delios and Beamish, 2001).

In airlines, intangible assets as capabilities contributing to competitiveness of a firm may be present in a wide variety of areas, including technologies, specialized skills, leadership and know-how for developing and offering competitive and attractive products and services, branding them as distinct and differentiated products and services, and efficiently and effectively managing airlines to deliver those products and services, among others. Furthermore, intangible assets may include organizational structure related to capital and ownership (Albers et al., 2010; Endo, 2010; Endo, 2017).

These assets shape a firm's competitive advantage regarding knowledge and organizational capability. Accordingly, airlines that possess such assets at a substantial level to make them feel confident about the ownership advantage may have the incentive to utilize them in foreign markets by pursuing FDI if host countries have location advantages, such as a host-country having a large market and a lower level of factor prices. This is so because the internalization advantage usually exists in many markets for the airline industry, as examined in the preceding literature review, and there are few incentives for an airline to license them to other airlines.

Hypothesis 1:

Airlines with a higher level of intangible assets have more incentives to invest in other airlines of a foreign country. 


\subsection{Institutional difference}

As examined in the literature review section, North (1990) highlighted that the institution defines the strategic options and corresponding utilities from which actors, including firms and individuals, may choose. Actors from a foreign institution (e.g., a foreign country) may pursue a different strategy under a similar situation, place different priorities on the same set of strategic options relative to a similar situation, or even provide different meanings for a similar situation. As a result, a less transparent institution and a large institutional difference between host and home countries may significantly impact FDI decisions.

As scholars such as Jackson and Deeg (2008), Peng (2004), and Endo et al. (2014) note, a firm may encounter the risk and uncertainty of conducting business in a foreign country whose institutions differ from those of the home country, leading to increased transaction costs of pursuing FDI. The firm is thus discouraged from fully committing itself to its foreign subsidiary in transferring intangible assets.

We argue that institutional difference between the home and host countries is a critically important factor that affects the ownership advantage and the location advantage of airlines in pursuing FDI. If the institutional difference is wide between the two countries, it may substantially undermine the ownership advantage and the location advantage of airlines, resulting in reducing the incentive for them to pursue FDI in entering into a foreign market.

As discussed in the literature review section, there are two forms of institutions, one being formal and the other being informal. Formal institutions define a wide spectrum of business activities including the scope of business, the governance structure, market regulations, supply chain, competitive relations, and employee relations, among others. For example, in airline industry, some governments may continue to maintain regulations both in breadth and depth, including business licensing regulations, antitrust law, foreign capital ownership restrictions, labour-related regulations, and safety and service quality regulations, among others, while other governments may have liberalized some, or many, of these regulations (Walulik, 2017). If a home country has a set of more liberalized regulations while a host country has a set of stricter regulations, the difference of formal institutions is identified to be wide.

The institutional difference may also exist in informal institutions and affect a wide spectrum of business activities including customer preference, interfirm relations, and employee relations. For example, in some societies, a casual and friendly manner may be considered a 
good airline service while in other societies, such a manner may be considered rude. In some societies, customers may put strong affinity to national brands of airlines while in other societies, they may put more importance on price and quality rather than to nationality (Havel and Sanchez, 2011; Clark, 2010). In some societies, employee relations may be more vertical and hostile, while in other societies, they may be more egalitarian and cooperative (Hall and Soskice, 2001).

They highlight that airlines may be faced with more difficulties adapting to local regulations, employee relations, customer preferences and other dimensions of national differences if institutional differences between home and host countries may be wide. Accordingly, the following hypothesis may be proposed:

Hypothesis 2:

Airlines have less incentive to undertake FDI in a foreign country whose institution is more different from that of the home country.

\section{METHODOLOGY}

To test these hypotheses, we examine airlines undertaking FDI in foreign (host) countries. Similar to Buch and Lipponer (2007), the data is the airline-host country combination, comprising of observations of the investment by airlines directing at foreign countries, as Table 1 shows. The sampling process is as follows. We choose airlines, excluding charter airlines and regional airlines, which the Airline Business magazine ranks in the top 90 regarding revenue passenger kilometre in 2015. We select the top 90 countries in the world (including Taiwan as a separate entity) as host countries (recipient countries of foreign investment) based on GDP of 2014. We delete those observations that do not have information about the variables.

The dependent variable is an investment decision by airlines directing at foreign countries. The data for foreign investment where airlines have more than $10 \%$ ownership in foreign airlines in 2015 and the first half of 2016, shown in Table 1, is collected from the Alliance Survey of the September 2016 edition of the Airline Business magazine, the annual reports of airlines, magazines and newspapers.

We realize that FDI by airlines directed to foreign airlines is not a commonplace phenomenon. The total number of FDI in the airline industry is around 80 , of which around 20 cases have 
missing information in some of the independent variables so that we may need to eliminate them from the examination. Because of the limited number of positive data, we aim at analysing the yes/no decision (i.e., what makes an airline to undertake/not-undertake FDI) rather than the in-degree decision (i.e., what makes an airline to undertake what level of FDI).

Table 1 - Foreign investments by airlines ranked in top 90 in terms of traffic: airlines having more than $\mathbf{1 0 \%}$ stock ownership shares in foreign airlines

\begin{tabular}{|c|c|}
\hline $\begin{array}{l}\text { Investing airlines/ } \\
\text { Home country }\end{array}$ & Recipient countries of foreign investment (Invested Airlines) \\
\hline AirAsia/Malaysia & $\begin{array}{l}\text { India(AirAsia), Indonesia(AirAsia, AirAsia X), Philippines(AirAsia), } \\
\text { Thai(AirAsia, AirAsia X) }\end{array}$ \\
\hline airberlin/Germany & Austria(Niki), Swiss(Belair) \\
\hline Air France/France & Netherlands(KLM) \\
\hline KLM/Netherland & France(Air France,Transavia),Kenya(Kenya) \\
\hline Azul/Brazil & TAP(Portugal) \\
\hline Avianca/Colombia & $\begin{array}{l}\text { Costa Rica(Avianca), Ecuador(Avianca), El Salvador(Avianca)*, } \\
\text { Guatemala(Avianca), Honduras(Avianca)*, Peru(Avianca) }\end{array}$ \\
\hline Copa/Panama & Colombia(Copa) \\
\hline Delta/US & UK(Virgin) \\
\hline easyJet/UK & Swiss(easyJet) \\
\hline Etihad/UAE & $\begin{array}{l}\text { Australia(Virgin)*, Germany(airberin)*, India(Jet)*, Italy(Alitalia)*, } \\
\text { Serbia(Serbia)*, Seychelles(Seychelles)*, Swiss(Darwin)* }\end{array}$ \\
\hline Hainan/China & Australia(Virgin), Brazil(Azul), France(Aigle Azur), Portugal(TAP) \\
\hline IAG:BA/UK & $\begin{array}{l}\text { France(OpenSkies), Ireland(Aer Lingus),Spain(Iberia, Vueling), South } \\
\text { Africa(Comair) }\end{array}$ \\
\hline Iberia/Spain & $\mathrm{UK}(\mathrm{BA})$ \\
\hline Korean/Korea & Czech(Czech) \\
\hline LAN/Chile & Argentina(LAN), Brazil(TAM), Colombia(LAN), Ecuador(LAN)\#, Peru(LAN) \\
\hline TAM/Brazil & Chile(LAN), Paraguay(TAM)* \\
\hline Lion/Indonesia & Malaysia(Malindo)*, Thai(Lion) $*$ \\
\hline Lufthansa/Germany & $\begin{array}{l}\text { Austria(Austria), Belgium(Brussel), Italy(Dolomiti), Switzerland(Swiss), } \\
\text { Turkey(SunExpress), US (JetBlue) }\end{array}$ \\
\hline $\begin{array}{l}\text { Air New Zealand/ } \\
\text { New Zealand }\end{array}$ & Australia(Virgin) \\
\hline Norwegian/Norway & Ireland(Norwegian)\#, UK(Norwegian)\# \\
\hline Qantas/Australia & Fiji(Fiji)*, Japan(Jetstar), Singapore(Jetstar), Vietnam(Jetstar) \\
\hline Qatar/Qatar & $\begin{array}{l}\text { Brazil(TAM),Chile(LAN), Ireland(Aer Lingus), Italy(Meridiana) } \\
\text { Spain(Iberia,Vueling), UK(BA) }\end{array}$ \\
\hline Singapore/Singapore & Australia(Virgin), India(Vistara)\#, Taiwan(Tiger)\# \\
\hline Spring/China & Japan(Spring) \\
\hline Virgin/UK & Australia(Virgin), Samoa(Virgin)*,US(Virgin) \\
\hline Volaris/Mexico & Costa Rica(Volaris)\# \\
\hline
\end{tabular}

Note: Investing airlines-host country combination observations marked by $*$ are not included in the statistical analysis because information for some independent variables is missing or because the observations are not from top 90 countries in terms of GDP. Investing airlines-host country combination observations marked by \# are not included in the statistical regression analysis when the dependent variable is operationalized by the secondary measure in the form of (1+RPKs) for robustness check because the information for such measure is missing in several FDI cases. Source: Alliance Survey of the September 2016 edition of the Airline Business magazine, annual reports of airlines, magazines and newspapers. 
As such, the dependent variable is operationalized by the binary dummy variable (FDI dummy) which takes the value of 1 when airlines invest in other airlines of a foreign country and have more than $10 \%$ stock ownership shares and which takes the value of zero when airlines do not make an investment in airlines of a foreign country or do not have more than $10 \%$ stock ownership shares there though they invest in foreign airlines. Since the dependent variable takes either the value of zero or one, OLS bears the risk of biased estimates (Greene, 2012; Maddala, 1992). Accordingly, we employ the logit method to analyse the impact on the binary dummy dependent variable.

In addition to the binary dummy variable as the primary measure for the dependent variable, we introduce the number of revenue passenger kilometres (RPKs) in 2014 or 2015 as the secondary measure to check the robustness of the estimation results. If airlines invest in foreign airlines and have more than $10 \%$ stock ownership shares there, the dependent variable is evaluated by RPKs. If airlines do not make an investment in foreign airlines or do not have more than $10 \%$ stock ownership shares even if they invest in such airlines, the variable takes the value of zero.

We take the logarithm of the secondary measure in the form of $(1+\mathrm{RPKs})$ to avoid the problem caused by the secondary measure taking the value of zero. Since the dependent variable operationalized by the secondary measure is cornered at the value of zero and non-negative and partly continuous, the Tobit model analysis is an appropriate statistical technique.

The secondary measure is more suitable to operationalize the incentive for FDI because it can capture more information about the decision process in FDI. We may be able to analyse the decision not only of whether airlines invest in foreign airlines but also to what degree they invest and commit. However, as we noted, the information is missing in several FDI cases. The Tobit model is critically dependent on the two assumptions, i.e., the normal distribution in error terms and heteroscedasticity (Greene, 2012; Mandala, 1992). In this respect, our data may not perfectly satisfy the two assumptions. Accordingly, we designate the binary dummy variable as the primary measure to focus on the estimation result of the variable.

We have two types of independent variables, the firm-level variable for airlines making FDI and the country-level variable of both home and host (foreign) countries. We offer the definitions and operationalization of the firm-level variable as follows. Regarding the variable for intangible assets that airlines may possess, the most commonly used measure in analysing the internationalization of a firm in the services sector is the advertising intensity ratio, as expressed by dividing advertising expenses by operating revenues. However, only a small 
number of airlines disclose these data. The training and education intensity ratio may be another well-established measure, but again, the data is not readily available for the airline industry.

Accordingly, in place of these measures, we use the percentage of intangible assets to total assets in the balance sheet (b/s intangible assets). This measure was introduced by Nachum (2003) in the analysis of the financial industry. Intangible assets reported in the financial statements of airlines include airport slots, trademarks, and goodwill, among others.

We also use such commonly used measures as the profitability (the percentage of operating incomes to operating revenues) and the load factor as proxies for intangible assets. The relevance and the limit of these measures have been examined in the preceding literature review section. Airlines possessing more intangible assets may be able to perform better, achieving higher ratios of these measures. The expected sign of the coefficient for the three measures of the intangible assets is positive. Employing the three different measures serves for checking the robustness of estimation results.

Other firm-level variables include the percentage of debt of airlines that have made FDI, expressed by dividing the debt by total assets (debt ratio), and the operational size of airlines as measured by the logarithm of RPKs (operation size). The expected sign of the coefficient for the two variables is negative and positive respectively. The information on such variables as b/s intangible assets, debt ratio, and profitability in 2014 or 2015 are collected from the ICAO database as main source as well as the Airline Business magazine and the annual reports of airlines as a secondary source. The data source of load factor and RPKs is the Airline Business magazine, the ICAO database, and the IATA publication.

Regarding the country-level variable, we use the World Bank's Governance Indicators to evaluate the institutional difference. They take scores from +2.5 to -2.5 in the following six fields: accountability, political stability, government effectiveness, quality of regulation, the legal system, and corruption control. The higher the score of such Indicators may be, the more transparent the institution of the country concerned may be.

Any dataset may have strengths and weaknesses. We selected the World Bank's Governance Indicators for the following reasons. First, they focus on the formal legal and regulatory institutions, which should have paramount importance for the airline industry. Second, they integrate such factors associated with informal institutions as accountability, stability, effectiveness, quality of regulation and corruption that may affect the formal legal and 
regulatory institutions. And finally, the Indicators have been widely tested and used by the IB scholars in conducting empirical studies to examine the impact of institutional difference on a firm FDI strategy. In short, not only the dataset is reliable, but also it measures the fields that are immediately relevant to the country-level factors of our study.

Regarding the operationalization of the institutional difference variable, in each field, we calculate the squares of the difference in the score of the relevant two countries (home and host countries) and divide the squares by the variance of the score among all the countries. We then calculate the average values of the six fields. The expected sign for the institutional difference variable is negative. We also add a binary dummy variable for a common language, which is one of the surrogate variables for capturing the difference between the institution in the cultural and normative aspects of the home and the host countries. The dummy variable takes a value of 1 if home and host countries use the same official language. The expected sign of the coefficient for the common language variable is positive.

We include the foreign stock ownership percentage cap set by the host country when foreign airlines invest in firms operating air transport services (foreign ownership cap) ${ }^{2}$. The cap variable may take a positive sign. Airlines may have more incentives for investing in a host country where such cap is high. The information for the variable is collected from the World Bank database and Walulik (2016). We incorporate economic factors of home and host countries, measured by the logarithm of GDP of such countries, collected from the World Bank database. The expected sign is negative and positive respectively.

\section{ESTIMATION RESULTS}

Tables 2 shows descriptive statistics as well as correlation coefficients between variables. The correlation coefficients are not high in most cases. Also, variance inflation factors (VIFs) are less than 10. Accordingly, any serious problem of multicollinearity is not observed. We use the White heteroscedasticity-consistent standard errors to cope with the problem of heteroscedasticity.

\footnotetext{
2 Only few countries (e.g. Australia) set different caps for locally licensed domestic operators and international operators. In this case, we choose the foreign stock ownership percentage cap regarding when foreign airlines invest in firms operating domestic air transport services.
} 
Table 2 - Descriptive statistics of variables and their correlation coefficients

\begin{tabular}{|r|l|r|r|r|r|r|r|r|r|r|r|r|}
\hline & 1 & 2 & 3 & 4 & 5 & 6 & 7 & 8 & 9 & 10 & 11 \\
\hline 1 & FDI dummy & 1 & & & & & & & & & & \\
\hline 2 & b/s intangible assets & 0.026 & 1 & & & & & & & & & \\
\hline 3 & load factor & 0.009 & 0.100 & 1 & & & & & & & & \\
\hline 4 & profitability & -0.014 & -0.070 & 0.280 & 1 & & & & & & & \\
\hline 5 & debt ratio & -0.038 & 0.285 & -0.109 & -0.176 & 1 & & & & & & \\
\hline 6 & operation size & 0.015 & 0.302 & 0.106 & 0.093 & -0.048 & 1 & & & & & \\
\hline 7 & institutional difference & -0.042 & 0.017 & 0.053 & -0.053 & -0.030 & 0.050 & 1 & & & & \\
\hline 8 & common language & 0.135 & 0.068 & 0.047 & 0.065 & 0.020 & 0.017 & -0.004 & 1 & & & \\
\hline 9 foreign ownership cap & 0.041 & 0.029 & 0.089 & -0.022 & 0.060 & 0.002 & -0.086 & 0.060 & & & \\
\hline 10 & home country GDP & -0.030 & 0.328 & 0.250 & 0.008 & 0.161 & 0.470 & 0.017 & 0.039 & -0.042 & & 1 \\
\hline 11 & host country GDP & 0.059 & -0.005 & -0.003 & -0.001 & -0.002 & -0.007 & -0.055 & 0.062 & -0.307 & -0.015 & 1 \\
\hline & mean & 0.016 & 4.918 & 81.303 & 3.870 & 84.728 & 10.946 & 1.841 & 0.072 & 62.030 & 14.226 & 12.830 \\
\hline & SD & 0.124 & 6.547 & 4.574 & 7.444 & 21.709 & 0.805 & 1.916 & 0.259 & 29.058 & 1.459 & 1.376 \\
\hline
\end{tabular}

Table 3 shows the estimation results. Model $1 a$ includes only the $b / s$ intangible assets percentage of the three measures of the intangible assets. Models $2 \mathrm{a}$ and $3 \mathrm{a}$ add load factor and profitability respectively. Models $1 b, 2 b$, and $3 b$ exclude the common language dummy variable from Models 1a, 2a, and 3a.

The coefficients of the $\mathrm{b} / \mathrm{s}$ intangible assets percentage are positive as predicted. They are statistically significant $(p<0.05)$. The load factor meets the sign condition in models $3 a$ and 3b. However, it is not statistically significant. The profitability shows the unexpected negative sign. We observe that these results weakly support Hypothesis 1. Regarding the other firmlevel factors, the debt ratio has the expected signs, and its coefficient is statistically significant $(p<0.01)$. The operation size satisfies the positive sign condition, but it is not statistically significant.

The two institutional variables take the expected signs in their coefficients which are statistically significant. The institutional difference meets the sign condition and works statistically significantly $(p<0.05)$. The coefficient of the common language dummy variable is positive as expected and highly statistically significant $(p<0.01)$. These results imply that if the institutional difference is larger between the home and host countries, airlines of the home country have fewer incentives in investing in other airlines of the host country. We observe that these results support Hypothesis 2.

The foreign ownership cap variable shows the expected positive sign, which is statistically significant $(p<0.01)$. The results demonstrate that airlines have more incentive to undertake FDI in a host country where the foreign stock ownership regulation is more liberalized. Home 
country GDP and host country GDP take expected signs. The coefficient of host country GDP variable is highly statistically significant $(p<0.01)$.

Table 3 - Estimation results: Dependent variables is FDI dummy

\begin{tabular}{|c|c|c|c|c|c|c|}
\hline & model 1a & model $1 \mathrm{~b}$ & model $2 a$ & model 2b & model 3a & model 3b \\
\hline \multirow[t]{2}{*}{ constant } & $-8.781 * * *$ & $-9.566 * * *$ & $-7.700 * *$ & $-9.106 * * *$ & $-9.189 * * *$ & $-10.59 * * *$ \\
\hline & $(2.782)$ & (2.869) & (3.071) & (3.135) & (3.461) & (3.611) \\
\hline \multirow[t]{2}{*}{ b/s intangible assets } & $0.039 * *$ & $0.051^{* *}$ & $0.041 * *$ & $0.051^{* *}$ & $0.041 * *$ & $0.052 * *$ \\
\hline & $(0.020)$ & $(0.020)$ & $(0.020)$ & $(0.020)$ & $(0.020)$ & $(0.021)$ \\
\hline \multirow[t]{2}{*}{ load factor } & & & -0.016 & -0.006 & 0.007 & 0.015 \\
\hline & & & $(0.026)$ & $(0.023)$ & $(0.029)$ & $(0.027)$ \\
\hline \multirow[t]{2}{*}{ profitability } & & & & & $-0.037 * *$ & $-0.035^{*}$ \\
\hline & & & & & $(0.016)$ & $(0.019)$ \\
\hline \multirow[t]{2}{*}{ debt ratio } & $-0.017 * * *$ & $-0.020 * * *$ & $-0.018 * * *$ & $-0.020 * * *$ & $-0.021 * * *$ & $-0.024 * * *$ \\
\hline & $(0.006)$ & $(0.007)$ & $(0.006)$ & $(0.007)$ & $(0.007)$ & $(0.007)$ \\
\hline \multirow[t]{2}{*}{ operation size } & 0.207 & 0.203 & 0.212 & 0.203 & 0.277 & 0.267 \\
\hline & $(0.172)$ & $(0.174)$ & $(0.176)$ & $(0.172)$ & $(0.188)$ & $(0.188)$ \\
\hline \multirow[t]{2}{*}{ institutional difference } & $-0.186 * *$ & $-0.190 * *$ & $-0.186 * *$ & $-0.191 * *$ & $-0.195 * *$ & $-0.197 * *$ \\
\hline & $(0.082)$ & $(0.089)$ & $(0.082)$ & $(0.090)$ & $(0.081)$ & $(0.088)$ \\
\hline \multirow[t]{2}{*}{ common language } & $1.890 * * *$ & & $1.903 * * *$ & & $1.953 * * *$ & \\
\hline & $(0.293)$ & & $(0.296)$ & & $(0.301)$ & \\
\hline \multirow[t]{2}{*}{ foreign ownership cap } & $0.018 * * *$ & $0.020 * * *$ & $0.018^{* * *}$ & $0.020 * * *$ & $0.018 * * *$ & $0.020 * * *$ \\
\hline & (0.005) & (0.005) & (0.005) & (0.005) & (0.005) & (0.005) \\
\hline \multirow[t]{2}{*}{ home country GDP } & $-0.233 * *$ & $-0.181^{*}$ & $-0.227 * *$ & $-0.178 *$ & $-0.277 * *$ & $-0.215^{*}$ \\
\hline & (0.105) & $(0.105)$ & $(0.102)$ & $(0.101)$ & $(0.118)$ & $(0.112)$ \\
\hline \multirow[t]{2}{*}{ host country GDP } & $0.424 * * *$ & $0.460 * * *$ & $0.433 * * *$ & $0.462 * * *$ & $0.425^{* * *}$ & $0.456 * * *$ \\
\hline & $(0.108)$ & (0.104) & (0.109) & $(0.105)$ & (0.109) & $(0.105)$ \\
\hline Log likelihood & -257.00 & -273.88 & -256.84 & -273.85 & -254.36 & -272.04 \\
\hline Chi-Square & 83.63 & 49.88 & 83.96 & 49.94 & 88.90 & 53.56 \\
\hline Positive observations & 58 & 58 & 58 & 58 & 58 & 58 \\
\hline Observations & 3716 & 3716 & 3716 & 3716 & 3716 & 3716 \\
\hline
\end{tabular}

We have checked the robustness of these estimation results by employing different measures for two major independent variables, the intangible assets, and the institutional difference. As pointed out, the results are not consistent among the three measures for the intangible assets, while the results are consistent between the two institutional difference measures.

Additionally, as mentioned, we performed the Tobit model analysis for the log (1+RPKs) as the alternative measure of the dependent variable. Table 4 shows the coefficient estimates based upon such analyses. Focusing on the two major independent variables, their results are consistent with those presented in Table 3 except for the b/s intangible assets percentage, 
which meets the sign condition but is not statistically significant when the common language dummy is included in models $1 \mathrm{a}, 2 \mathrm{a}$ and $3 \mathrm{a}$ in Table 4.

Table 4 - Estimation results for robustness check: Dependent variable is (1+RPKs)

\begin{tabular}{|l|r|r|r|r|r|r|}
\hline & model 1a & model 1b & model 2a & model 2b & model 3a & model 3b \\
\hline constant & $-107.1^{* * *}$ & $-109.5 * * *$ & $-91.24 *$ & $-98.92^{* *}$ & $-117.0^{* *}$ & $-115.2^{* *}$ \\
b/s intangible assets & $(15.45)$ & $(15.80)$ & $(51.70)$ & $(49.36)$ & $(52.15)$ & $(50.44)$ \\
& 0.570 & $1.033^{* *}$ & 0.586 & $1.046 * *$ & 0.552 & $1.033^{* *}$ \\
load factor & $(0.458)$ & $(0.474)$ & $(0.463)$ & $(0.478)$ & $(0.462)$ & $(0.477)$ \\
& & & -0.194 & -0.129 & 0.200 & 0.131 \\
profitability & & & $(0.605)$ & $(0.574)$ & $(0.631)$ & $(0.617)$ \\
& & & & & -0.602 & -0.429 \\
debt ratio & & & & & $(0.428)$ & $(0.477)$ \\
& $-0.360^{* *}$ & $-0.381^{* * *}$ & $-0.365^{* * *}$ & $-0.385 * * *$ & $-0.406 * * *$ & $-0.418^{* * *}$ \\
operation size & $(0.142)$ & $(0.148)$ & $(0.141)$ & $(0.147)$ & $(0.156)$ & $(0.162)$ \\
& 6.063 & 4.981 & 5.975 & 4.901 & $6.823 *$ & 5.503 \\
institutional difference & $(3.870)$ & $(4.036)$ & $(3.758)$ & $(3.901)$ & $(3.966)$ & $(4.130)$ \\
& $-4.046 * *$ & $-4.566 * *$ & $-4.015 * *$ & $-4.550 * *$ & $-4.179 * *$ & $-4.674 * *$ \\
common language & $(1.877)$ & $(2.020)$ & $(1.849)$ & $(1.997)$ & $(1.799)$ & $(1.951)$ \\
& $42.58^{* * *}$ & & $42.62^{* * *}$ & & $43.62^{* * *}$ & \\
foreign ownership cap & $(5.753)$ & & $(5.767)$ & & $(5.768)$ & \\
& $0.357 * * *$ & $0.421 * * *$ & $0.363 * * *$ & $0.425 * * *$ & $0.353^{* * *}$ & $0.417 * * *$ \\
home country GDP & $(0.119)$ & $(0.120)$ & $(0.121)$ & $(0.123)$ & $(0.120)$ & $(0.122)$ \\
& -3.735 & -3.484 & -3.572 & -3.369 & $-4.188^{*}$ & -3.757 \\
host country GDP & $(2.407)$ & $(2.428)$ & $(2.226)$ & $(2.250)$ & $(2.340)$ & $(2.325)$ \\
& $10.07 * * *$ & $10.70 * * *$ & $10.13^{* * *}$ & $10.73 * * *$ & $9.968 * * *$ & $10.61^{* * *}$ \\
Log likelihood & $(2.282)$ & $(2.282)$ & $(2.276)$ & $(2.282)$ & $(2.268)$ & $(2.273)$ \\
Chi-Square & & & & & & \\
Positive observations & -447.01 & -462.51 & -446.97 & -462.23 & -445.84 & -461.73 \\
Observations & 76.20 & 45.20 & 76.28 & 45.76 & 78.54 & 46.76 \\
& 52 & 52 & 52 & 52 & 52 & 52 \\
& 3710 & 3710 & 3710 & 3710 & 3710 & 3710 \\
\hline
\end{tabular}

\section{CONCLUSION AND DISCUSSION}

This paper examined the determinants of FDI in the airline industry by using the Eclectic Paradigm model. The model is a dominant approach in the international business studies to analyse FDI. Major determinants include both the firm-level ones, represented by intangible assets that constitute the foundation of the competitiveness of individual airlines and the country-level ones, represented by the institutional difference between home and host countries that may constrain airlines in transferring intangible assets across countries.

As noted, very few past studies have employed the model based upon the regression analysis to examine the airline industry. Let us start our discussion with the general observation: 
Overall, the Eclectic Paradigm model is relevant to the airline industry. It highlights the importance of both firm-level resources and capabilities (Ownership advantage) and countrylevel factors (Location and Internalization advantages). Our results indicate that airlines are making a rational and functional decision on FDI just like firms in other industries do by calculating these different levels of factors.

They demonstrate patterns that are generally similar to firm behaviours of other industries that the Eclectic Paradigm model posits. If they are well-managed and competitive and if they believe the competitiveness arises from their resources and capabilities, they may be tempted to expand internationally by taking advantage of them. When they expand internationally, they may want to undertake FDI to control their foreign subsidiaries so that they may exploit their resources and capabilities, the firm-level ownership advantage, to establish competitiveness in foreign markets.

One may also note that the room for the government to intervene in FDI of an airline is much larger as compared with that of other industries. The level of intervention may vary from a country to another. Airlines are likely to encounter the risk and uncertainty of doing business in a foreign country that has different, and especially less transparent, institutions. Airlines' foreign subsidiaries may encounter substantial "liability of foreignness" in doing business in institutionally different countries, which is translated into a higher level of additional costs to operate in a foreign market. Furthermore, institutional constraints for airlines may be substantially higher compared with other industries as many governments have restrictive regulatory regimes. Airlines may be more incentivized to pursue FDI in a country with familiar and transparent institutions and a more liberal regulatory regime for the airline industry, while they may be less incentivized to pursue FDI in a country with unfamiliar and less transparent institutions and a more restrictive regulatory regime.

In the old days, insights from international economics made us believe that factor endowment was the single most important reason for a firm to decide on a location. We are developing insights into institutions that may play an important role for a firm to decide whether and in which country to pursue FDI.

Beyond this observation, a few discussion points may be made. As for the firm-level determinants, the empirical results indicate that airlines with a higher level of intangible assets have more incentives to invest in other airlines of a foreign country. However, a positive effect of the intangible assets on FDI decision is weakly supported because the b/s intangible assets 
measure for the intangible assets independent variable is statistically significant but the other two measures are not so. These results may lead to the following observations.

First, the institutional factors may affect airlines more significantly than the firm-level factors may in their FDI decision. Second, even though we observe that the airlines may most likely be not much different from other industries when it comes to the importance of the firm-level factors for the FDI decision, we also recognize that we have a limitation under both the absolutely small number of the FDI cases in the airline industry and the current level of the availability of information. The limitation may be twofold.

One is the weakness of the measures in analysing the intangible assets. As noted earlier, the most common such measure employed in the services sector is the advertising intensity ratio, as expressed by dividing advertising expenses by operating revenues. The training and education intensity ratio may be another commonly used measure. Unfortunately, only a small number of airlines are disclosing these data, and as such, we pursued a second-best option, i.e., the balance sheet intangible assets as well as load factor and profitability. The quality of data may have some impact on the level of statistical significance. Further study regarding the quality of the dataset and the examination of alternative proxy variables may be necessary.

Another is the possibility of a lesser relevance of the intangible assets of the airline industry in FDI as compared with other industries. As discussed in the literature review section, a few observations note that airlines are distinctly national, hence they are uniquely different from other regular business. They are often protected from competition by regulatory regimes, and airline brands may have significant "national connotations" for home-country customers, as noted in the literature review section (Havel and Sanchez, 2011; Wassenbergh, 2004). Accordingly, resources and capabilities that contribute to firm-level competitive advantage in other industries may be of limited use for airlines.

However, we note that this possibility has been addressed by introducing the institutional difference. As discussed in the literature review section, protective regulatory barriers and local customer bias have been identified as institutional differences that may constrain a foreign firm when entering a host country market. One important possibility specific to the airline industry may be that the institutional difference for the airline industry arising from regulatory barriers and local customer bias may play much strongly as compared to that for other industries. Here, further study may be necessary for examining how we construct the institutional difference. 
As for the country-level determinants, our analysis joins a growing number of IB studies that underscore the significance of institution for FDI. The empirical results support, even if not unambiguously, that airlines have fewer incentives for making FDI in other airlines of institutionally different countries. Institutionally different countries may be either those that have legal, regulatory and other formal rules that are relatively different from those of one's own country or those that have different social, cultural and other informal rules that are relatively different from those of one's own country. Furthermore, considerable variation exists among countries in the absolute level of the government restriction on foreign ownership of the airline. It may become a major factor that discourages airlines to pursue FDI in such a country.

The level of statistical significance of our study prompts us to explore possible issue areas that may require further studies. On the one hand, we realize that the airline industry has a few unique characteristics that might moderate the impact of institutional difference upon an FDI strategy for the airline industry. For example, the industry is characterized by large network effects that may compel airlines to internationalize irrespective of institutional difference. It may also be characterized by the international regulatory regime that may harmonize operation across countries.

On the other hand, we also realize that the airline industry has characteristics unique to consumer-oriented services industries that might increase the impact of institutional difference upon an FDI strategy. Service industries are distinctly different from manufacturing industries in which the former usually require production and consumption to take place simultaneously while the latter allow their separation. The result is a higher level of exposure of services firms to host country contexts in which the co-creation process between producers and consumers takes place. This process is usually associated with a higher level of pressure to localize operation, including the localization of services and relationship marketing (Grönroos, 1982; Khojastehpour and Johns, 2015)

We thus need to examine these seemingly competing forces, which may be uniquely associated with the airline industry, and their impact on an FDI strategy. When doing so, we may also need to take into account the fact that most airline FDI cases involve equity partners, many of which are local firms of host countries. They may reflect the fact that many countries restrict foreign ownership by laws. However, the international business studies also indicate the important role of local equity partners when the institutional difference between home 
and host countries is wide. These local partners may provide knowledge and expertise to help cope with "liability of foreignness" in entering a foreign market.

We realize that our study leads to a wide-open room for further studies. We nonetheless believe that our study provides initial evidences to indicate the relevance and the importance of the theoretical framework drawn from the international business studies to an FDI strategy of the airline industry. We also believe that it highlights the areas requiring more thorough theoretical investigation and empirical testing, including the identification of additional variables, and the accumulation of appropriate data.

\section{ACKNOWLEDGMENTS}

Nobuaki Endo was supported by JSPS KAKENHI Grant Number JP16K03612.

\section{REFERENCES}

- Albers, S., Heuermann, C. and Koch, B. (2010). 'Internationalization strategies of EU and Asia-Pacific low fare airlines', Journal of Air Transport Management, 16(5), 244-250.

- Anderson, E. and Gatignon, H. (1986). 'Modes of Foreign Entry: A Transaction Cost Analysis and Propositions', Journal of International Business Studies, 17(3), 1-26.

- Ando, N. (2012). 'The ownership structure of foreign subsidiaries and the effect of institutional distance: a case study of Japanese firms', Asia Pacific Business Review, 18(2), 259-274.

- Barney, J. B. (1991). 'Firm Resources and Sustained Competitive Advantage', Journal of Management, 17(1), 99-120.

- Brouthers, K. D. (2002). 'Institutional, cultural and transaction cost influences on entry mode choice and performance', Journal of International Business Studies, 33(2), 203-221.

- Bouquet, C., Hébert, L. and Delios, A. (2004). 'Foreign expansion in service industries: Separability and human capital intensity', Journal of Business Research, 57(1), 35-46.

- Buch, C. M. and DeLong, G. (2004). 'Cross-border bank mergers: What lures the rare animal', Journal of Banking \& Finance, 28(9), 2072-2102.

- Buch, C. M. and Lipponer, A. (2007). 'FDI versus exports: Evidence from German banks', Journal of Banking \& Finance, 31(3), 805-826.

- Buckley, P. J. (2002). 'Is the International Business Research Agenda Running Out of Steam', Journal of International Business Studies, 33(2), 365-373.

- Caves, R. E. (1971). 'International Corporations: The Industrial Economics of Foreign Investment', Economica, 38(149), 1-27.

- Caves, R. E. (1982). Multinational Enterprise and Economic Analysis, Cambridge U.K.: Cambridge University Press.

- Caves, R. E. and Jones, R. W. (1985). World Trade and Payments, Boston: Little, Brown.

- Cerutti, E., Dell'Ariccia, G. and Pería, M. (2007). 'How banks go abroad: Branches or subsidiaries?', Journal of Banking and Finance, 31(6), 1669-1692. 
- Clark, P. (2010). Stormy Skies: Airlines in Crisis, Burlington, VT: Ashgate.

- Chang,Y.-C., Williams, G. and Hsuaet, C.-J. (2004). 'The evolution of airline ownership/control provisions', Journal of Air Transport Management, 10(3), 161-172.

- Delios, A. and Beamish, P. W. (2001). 'Survival and Profitability: The Roles of Experience and Intangible Assets in Foreign Subsidiary Performance', Academy of Management Journal, 44(5), 1028-1038.

- Dunning, J. R. (1988). 'The Eclectic Paradigm of International Production: A Restatement and Some Possible Extensions', Journal of International Business Studies, 19(1), 1-31.

- Dunning, J. R. (2000). 'The eclectic paradigm as an envelope for economic and business theories of MNE activity', International Business Review, 9(2), 163-190.

- Eden, L. and Miller, S. (2004). DISTANCE MATTERS: LIABILITY OF FOREIGNNESS, INSTITUTIONAL DISTANCE AND OWNERSHIP STRATEGY. In Hitt, M, A. and Cheng, J. L. C. (ed.) Theories of the Multinational Enterprise: Diversity, Complexity and Relevance (Advances in International Management, Volume 16), Emerald Group Publishing Limited, $187-221$.

- Endo, N. (2010). 'Examination of Multinationalization and Internationalization in Airline Business: Impact on Performance from Viewpoints of International Business Studies', Unpublished paper presented at The 2010 ATRS Conference, Porto, Portugal.

- Endo, N. (2017). 'Determinants of Foreign Direct Investment in Airline Industry', Japan Society for Transportation Economics Journal, 60. (in Japanese)

- Endo, N. and Ozaki, T. (2009). 'Choice of Foreign Market Entry Mode: Examination of Japanese Service Firms', Unpublished paper presented at The 2009 Academy of International Business Conference, San Diego, California.

- Endo, N. and Ozaki, T. (2011). 'The Effect of Multinationality on Firm Performance: Examination of Japanese Service Firms', Asian Business and Management, 10(1), 133-150.

- Endo, N., Ozaki, T. and Ando, N. (2011). 'Determinants of Foreign Subsidiary Performance among Japanese Service Firms', Unpublished paper presented at The 2011 Association of Japanese Business Studies Conference, Nagoya, Japan.

- Endo, N., Ozaki, T. and Ando, N. (2014). 'Firm-level Factor Versus National Institutional Difference: Ownership Structure in a Foreign Subsidiary of a Japanese Logistics Firm', The Asian Journal of Shipping and Logistics, 30(3), 393-413.

- Ferreira, M. P., Pinto, C. F., Serra, F. A. R. and Gaspar, L. F. (2011). 'International Business/Strategy Research: A Bibliometric Study in the Strategic Management Journal', Journal of Strategic Management Education, 7(2), 1-23.

- Franco-Arroyave, C., Martins-Cheze, A., Siegel, E. and Vásquezet, J. C. D. (2014). 'Internationalization strategies of a Multilatina in the service sector: Avianca-Taca holdings S.A. case study', $A D$-minister, 25, 79-96.

- Gaur, A. S. and Lu, J. W. (2007). 'Ownership Strategies and Subsidiary Performance: Impacts of Institutional Distance and Experience', Journal of Management, 33(1), 84-110.

- Grant, R. M. (1987). 'Multinationality and Performance among British Manufacturing Companies', Journal of International Business Studies, 18(3), 79-89.

- Grant, R. M. (1996). 'Prospering in Dynamically-Competitive Environments: Organizational Capability as Knowledge Integration', Organization Science, 7(4), 375-387

- Greene, W. H. (2012). Econometric analysis, Boston : Pearson. 
- Grönroos, C. (1982).'An Applied Service Marketing Theory', European Journal of Marketing, 16(7), 30-41.

- Hall, P. A. and Soskice, D. W. (2001). Varieties of Capitalism; The Institutional Foundations of Comparative Advantage, Oxford UK: Oxford University Press

- Havel, B. F. and Sanchez, G. S. (2011). 'Restoring Global Aviation's Cosmopolitan Mentalité', Boston University International Law Journal, 29(1), 1-40.

- Hill, C. (2014). Global business today, New York: McGraw Hill.

- Hitt, M. A., Hoskisson, R. E. and Kim, H. (1997). 'International Diversification: Effects on Innovation and Firm Performance in Product-Diversified Firms', Academy of Management Journal, 40(4), 767-798.

- Hocking, A. J. (2011). 'Ownership and Control in Australia's Air Services Agreements: Further Reform Needed for Genuine Commercial Freedom?', Annals of Air and Space Law, 36, 29-79.

- Hymer, S. (1976). The International Operations of National Firms: A Study of Direct Foreign Investment, Cambridge, MA: MIT Press.

- Jackson, G. and Deeg, R. (2008). 'Comparing capitalisms: understanding institutional diversity and its implications for international business', Journal of International Business Studies, 39(4), 540-561.

- Khojastehpour, M. and Johns, R. (2015), 'From pre-internationalization to postinternationalization: relationship marketing perspective', Journal of Strategic Marketing, 23(2), 157-174.

- Knickerbocker, F. T. (1973). Oligopolistic Reaction and Multinational Enterprise, Cambridge, MA: Harvard University Press.

- Lu, J. W. and Beamish, P. W. (2004). 'International Diversification and Firm Performance: The S-curve Hypothesis', Academy of Management Journal, 47(4), 598-609.

- Maddala, G. S. (1992). Introduction to Econometrics, New York : Macmillan

- Meyer, K. (2001). 'Institutions, Transaction Cost and Entry Mode Choice in Eastern Europe', Journal of International Business Studies, 32(2), 357-367.

- Nachum, L. (2003). 'Liabilities of Foreignness in Global Competition?', Strategic Management Journal, 24(12), 1187-1208.

- Narula, R. (2010). 'Keeping the Eclectic Paradigm Simple', Multinational Business Review, $18(2), 35-50$

- North, D. C. (1990). Institutions, Institutional Change and Economic Performance, Cambridge UK: Cambridge University Press.

- Peng, M. W. (2004). 'Identifying the big question in international business research', Journal of International Business Studies, 35(2), 99-108.

- Peteraf, M. A. (1993). 'The cornerstones of competitive advantage: A resource-based view', Strategic Management Journal, 14(3), 179-191.

- Ramón-Rodríguez, A. B., Moreno-Izquierdo, L. and Perles-Ribes, J. F. (2011). 'Growth and internationalization strategies in the airline industry', Journal of Air Transport Management, 17(2), 110-115.

- Rugman, A., M. and Verbeke, A. (2003). 'Extending the theory of the multinational enterprise: internalization and strategic management perspectives', Journal of International Business Studies, 34(2), 125-137. 
- Vernon, R. (1966). 'International Investment and International Trade in the Product cycle', The Quarterly Journal of Economics, 80(2), 190-207.

- Wassenbergh, H. (2004). 'The International Airline Industry: The Straitjacket of Competition Law', Annals of Air and Space Law, 29, 185-199.

- Walulik, J. (2016). 'At the core of airline foreign investment restrictions: A study of 121 countries', Transport Policy, 49, 234-251.

- Walulik, J. (2017). Progressive Commercialization of Airline Governance Culture, London UK: Routledge. 